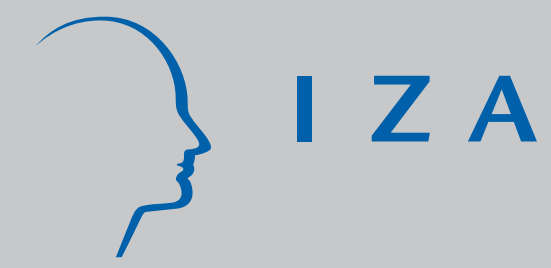

IZA DP No. 346

The Determination of a Migration Wave Using Ethnicity and Community Ties

Lilo Locher

August 2001 


\title{
The Determination of a Migration Wave Using Ethnicity and Community Ties
}

\author{
Lilo Locher \\ Bonn Graduate School of Economics and IZA, Bonn
}

Discussion Paper No. 346

August 2001

\author{
IZA \\ P.O. Box 7240 \\ D-53072 Bonn \\ Germany \\ Tel.: $+49-228-3894-0$ \\ Fax: +49-228-3894-210 \\ Email: iza@iza.org
}

This Discussion Paper is issued within the framework of IZA's research area Mobility and Flexibility of Labor Markets. Any opinions expressed here are those of the author(s) and not those of the institute. Research disseminated by IZA may include views on policy, but the institute itself takes no institutional policy positions.

The Institute for the Study of Labor (IZA) in Bonn is a local and virtual international research center and a place of communication between science, politics and business. IZA is an independent, nonprofit limited liability company (Gesellschaft mit beschränkter Haftung) supported by the Deutsche Post AG. The center is associated with the University of Bonn and offers a stimulating research environment through its research networks, research support, and visitors and doctoral programs. IZA engages in (i) original and internationally competitive research in all fields of labor economics, (ii) development of policy concepts, and (iii) dissemination of research results and concepts to the interested public. The current research program deals with (1) mobility and flexibility of labor markets, (2) internationalization of labor markets and European integration, (3) the welfare state and labor markets, (4) labor markets in transition, (5) the future of work, (6) project evaluation and (7) general labor economics.

IZA Discussion Papers often represent preliminary work and are circulated to encourage discussion. Citation of such a paper should account for its provisional character. 
IZA Discussion Paper No. 346

August 2001

\section{ABSTRACT \\ The Determination of a Migration Wave Using Ethnicity and Community Ties*}

If people come to live in a country different from their nation state, due to border shifts, expulsion, or migration, they adopt some of the new country's habits after some time. This paper investigates their (return) migration decision when they have been restricted to live in the foreign country for some time and suddenly become free to return to the country of their original nationality. In our model, the population is located in small communities on a Hotelling line. The two poles represent the two nationalities. Utility depends on distance to the pole and to the center of the community someone is living in. Looking at ethnic German migration in the 1990s, we compare basic features of the migration wave with assumptions of the model, compare actual and predicted migration waves and discuss the impact of immigration restrictions.

JEL Classification: $\quad F$ 22, H11, H79, J11, J15, R23

Keywords: Migration decision, migration networks, Hotelling model, ethnic Germans

Lilo Locher

IZA

P.O. Box 7240

D-53072 Bonn

Germany

Tel.: +492283894531

Fax: +492283894510

Email: locher@iza.org

\footnotetext{
* I would like to thank Barbara Dietz from the Osteuropa Institute in Munich for providing the data and Ira Gang, Andreas Wiggers and Rainer Winkelmann for helpful comments.
} 


\section{Introduction}

In spite of large wage differences and no barriers to migration between countries, there is often not much migration from the poor to the rich country, and sometimes we observe large-scale migration in the opposite direction. An example for the first kind of behavior is the small degree of migration from the Southern to the Middle and Northern countries of the EU, an example for the second kind is migration from the US and Western Europe to Israel. In the first case, huge migration costs, mostly psychic, can account for the large wage differences that are necessary to induce migration. However, since migration costs incur only during the process of resettlement and remain more or less constant over time, in those cases in which migration actually takes place, it should take place as early as possible. Yet, what we observe is that migration opportunities take a considerable amount of time to be taken.

Several papers explain migration inertia with an option value approach (e.g. Burda (1993, 1995), Burda et al. (1998), O'Connell (1997)). In some cases, this is convincing. For example, it was reasonable to be uncertain about the persistence of wage differences between East and West Germany in 1990. In other cases, the persistence of large wage differences seems to be something there is no uncertainty about. Most countries of the former Soviet Union will be much poorer than Germany for many more years to come, and even a positive scenario for the development of the Kazakh economy will diminish wage differences between Germany and Kazakhstan only to a small degree. Another explanation for inertia is migration networks. Bauer and Zimmermann (1997a, 1997b) show that they are empirically important. However, there is no model of how the network builds up. If migration costs are lower in case there is already a network in the receiving country, it is hard to explain how the migration process starts. Epstein and Hillman (1998) have a model of informational cascades, in which the migration decision takes place sequentially. This circumvents the problem of how migration starts and gives an explanation for an increase in a migration rate over time. Hatton (1995) has empirical evidence for this phenomenon.

In this paper we present a model of migration, which can explain both nonmigration (migration) in case of a positive (negative) wage difference and procrastination within a migration wave of one cohort. Our framework is applicable to migration in case the potential migrants live in a country that is not their nation state. This can happen because of voluntary migration, expulsion, or border shifts. For example, guest workers in Western Europe and European colonists in former colonies may con- 
sider returning to their country of origin. Since 1948, the Jewish people has the possibility to return to the country it has been expelled from in 70 A.D. Russians who moved to other republics of the Soviet Union have now become minorities in the new-founded national states of the CIS, so that many of them move back to Russia. The border shifts after the two World Wars created a large number of minorities, e.g. a Hungarian minority in Romania and a German minority in Poland. In this paper, we have a closer look at the migration of ethnic Germans to Germany from Eastern Europe and the former Soviet Union, which emerged in the late 1980s after the breakdown of the Eastern block. We simulate the migration waves with and without taking Germany's immigration restrictions into account. Comparing our simulations with the actual form of the migration waves, we find that the restrictions were not binding for Romania and Poland, whereas they seriously distorted the migration process from Russia, Kyrgyzstan and Kazakhstan.

To model the migration process, we use a Hotelling framework in which a group of potential migrants is distributed on a line, where the position on the line depicts the degree to which someone feels attached to his resident or to his nation country. Also, people live in communities that are ordered on the line. Individual utility decreases in the distance to his resident country and to the center of the community he is living in. Alesina and Spoalore (1997) use this framework to analyze the number or size of nations if preferences for the variety of a public good are heterogeneous. There are several other papers in that spirit; an overview is in Bolton, Roland, and Spolaore (1996). We copy their framework and reinterpret "nations" as "communities", and horizontal product differentiation of the public good as the degree to which someone is attached to the culture of either his resident or his nation country. The main impact of this literature is on the equilibrium number and size of nations under different regimes. We take the number and size of communities as exogenously given. Instead, we concentrate on the transition from an equilibrium in which everybody is confined to live in the foreign country to a new equilibrium in which location in two countries is possible. The two forces that drive the process are the relation to the country of residence and the nation state, reflected by the distance to the poles, and community ties, reflected by the distance to the center of one's community. What we call a "community" can just be a group of friends, acquaintances, and colleagues. As usual in this literature, we assume emotional and spatial distance to coincide. First, some kind of spatial proximity is, even if not necessary, very helpful for a relation to some- 
body else. Second, there is a large degree of residential segregation among ethnic minorities. This has been analyzed in detail for the US society. Borjas (1998), table 4 has a list of residential segregation in the NLSY, by national-origin group. For other ethnic groups in other countries, we observe the same.

The rest of the paper is structured as follows. In section 2, we present the model. In section 3, we discuss ethnic German migration in the light of this model, analyzing in how far the characteristics of the model fit stylized facts about the migration wave. In section 4, we simulate the migration waves created by the model and compare our results with the actual migration waves for five countries of origin of ethnic Germans. Section 5 concludes.

\section{A spatial model of migration}

\subsection{The equilibrium for residence in two countries}

We look at a population, uniformly distributed on a Hotelling line of length 1, with $\mathrm{x}=0$ and $\mathrm{x}=1$ representing two nation states, which we label as $\mathrm{A}$ for $\mathrm{x}=0$ and $\mathrm{B}$ for $\mathrm{x}=1$. The population feels attached to both countries, each individual according to his location on the line. The population is an outsider group or a minority in each of the two countries, as the "normal" citizen is located at the respective pole. $\mathrm{P}_{\mathrm{A}}$ is the part of the population residing in country $\mathrm{A}, \mathrm{P}_{\mathrm{B}}$ is the part residing in country $\mathrm{B}$. The total population is normalized to one, i.e.

$$
\mathrm{P}_{\mathrm{A}}+\mathrm{P}_{\mathrm{B}}=1 \text {. }
$$

Utility of each individual decreases in the distance between his location on the line and the pole of the country he is living in. Also, utility depends on the distance to the center of the community the individual lives in. People can choose whether to live completely assimilated in the country in which they stay, or whether they live in a community with others of the minority population. We call the average $\mathrm{x}$ of a community the center of a community $\overline{\mathrm{x}}$, with utility decreasing in distance to the center of the community a person is living in. The community center of a person who is completely assimilated is 0 if he stays in A, and 1 if he stays in B. The utilities of living in countries $\mathrm{A}$ and $\mathrm{B}$ are thus defined as

$$
\begin{array}{lll}
U_{A}^{i}=-\left|x^{i}-\bar{x}_{A}^{1}\right|-a_{A}\left|x^{i}-0\right| & =-\left|x^{i}-\bar{x}_{A}^{1}\right|-a_{A} x^{i} & a_{A}>0 \\
U_{B}^{i}=-\left|x^{i}-\bar{x}_{B}^{1}\right|-a_{B}\left|x^{i}-1\right|+b & =-\left|x^{i}-\bar{x}_{B}^{1}\right|-a_{B}\left(1-x^{i}\right)+b & a_{B}>0
\end{array}
$$


with $\overrightarrow{\mathrm{x}}_{\mathrm{A}}^{1}$ and $\overline{\mathrm{x}}_{\mathrm{B}}$ as the center of the community the person is living in in country A and $\mathrm{B}$, respectively. The parameter $\mathrm{b}$ in the utility function for country $\mathrm{B}$, which may be negative, captures the additional utility of living in country B as opposed to A due to economic or political differences in the two countries. It also covers migration costs. ${ }^{1}$ The two weighting parameters, $\mathrm{a}_{\mathrm{A}}$ and $\mathrm{a}_{\mathrm{B}}$, measure how important the country preference compared to the community preference is in each of the countries. The parameters are allowed to differ across countries, because this allows us to describe a situation in which a minority has more autonomous rights in one country. In that case, the weighting parameter a would be smaller for that country.

To avoid that each utility-maximizing person makes up a community of his own, we set the minimum size of a community equal to $\gamma>0$. In this model, $\gamma$ is exogenously given, but there are several papers that derive $\gamma$, e.g. Alesina and Spolaore (1997). In their model, each community provides a public good, which is produced at a certain cost. In a larger community, costs per person of providing the public good are lower, but tastes concerning the characteristics of the public good are less satisfied on average. In equilibrium, communities all have the same size, they are ordered one after the other on the Hotelling line, ${ }^{2}$ and the public good provided is equal to the tastes of the person living in the center of the community. These results carry over to our model, except that the size of communities can be different in the two countries.

We denote the number of people living in each community by $\mathrm{n}_{\mathrm{A}}$ and $\mathrm{n}_{\mathrm{B}}$, respectively. $\mathrm{N}_{\mathrm{A}}$ and $\mathrm{N}_{\mathrm{B}}$ is the number of communities in $\mathrm{A}$ and $\mathrm{B}$. Using the three equilibrium conditions about size, location and structure of communities, we get

$$
\mathrm{N}_{\mathrm{A}}=\max \left\{\left\lfloor\frac{\mathrm{P}_{\mathrm{A}}}{\gamma}\right\rfloor-\frac{1}{2}, 0\right\}
$$

\footnotetext{
${ }^{1}$ In most migration models, migration costs make up a crucial element. To justify their quasi-omission here, note that our model explicitly takes community ties into account and that the kind of migration we have in mind is a different one than what is usually considered. The bulk of migration costs usually are labeled as psychic costs of migration. These costs are explicitly modeled here using community ties. It seems plausible that there are high costs of leaving a community, however, if the community itself dissolves due to emigration of others, it is no longer more difficult to leave than to stay. Also, conventional migration models look at migration to a new country. In our case, the country people are moving to is a home-country in terms of nationality. Not only that this further reduces the psychic costs of migration, typically, it also reduces monetary costs, as the nation state they are moving to is interested in them to come. Typically, it is easier to get citizenship in the new country, and thus get access to the benefits of the social security system, and, in addition to that, many countries offer some extra help in the beginning.

${ }^{2}$ If two persons with $x^{i}$ and $x^{i}$ live in the same community and $x^{i}>x^{i}$, every person with $\mathrm{x}^{\mathrm{j}}: \mathrm{x}^{\mathrm{i}}>\mathrm{x}^{\mathrm{j}}>\mathrm{x}^{\mathrm{i}}$ also lives in the community.
} 


$$
\begin{aligned}
& \mathrm{N}_{\mathrm{B}}=\max \left\{\left\lfloor\frac{\mathrm{P}_{\mathrm{B}}}{\gamma}\right\rfloor-\frac{1}{2}, 0\right\} \\
& \mathrm{n}_{\mathrm{A}}= \begin{cases}\frac{\mathrm{P}_{\mathrm{A}}}{\left(\mathrm{N}_{\mathrm{A}}+1 / 2\right)} & \text { if } \mathrm{N}_{\mathrm{A}}>0 \\
0 & \text { otherwise }\end{cases} \\
& \mathrm{n}_{\mathrm{B}}= \begin{cases}\frac{\mathrm{P}_{\mathrm{B}}}{\left(\mathrm{N}_{\mathrm{B}}+1 / 2\right)} & \text { if } \mathrm{N}_{\mathrm{B}}>0 \\
0 & \text { otherwise }\end{cases}
\end{aligned}
$$

So far, we have six unknowns, population, community size, and community number for each of the two countries, but only five equation, (1) and (4) to (7). The sixth equation comes from the condition that the person located at the point on the line on which the populations of the two countries meet must be indifferent between residence in $\mathrm{A}$ and $\mathrm{B}$. Calculating $\mathrm{x}^{\mathrm{i}} *$ for which $\mathrm{U}_{\mathrm{A}}^{\mathrm{i}}=\mathrm{U}_{\mathrm{B}}^{\mathrm{i}}$, and setting this equal to $\mathrm{P}_{\mathrm{A}}$, we get

$$
\mathrm{P}_{\mathrm{A}}=\max \left\{\frac{1+\mathrm{n}_{\mathrm{A}} \mathrm{N}_{\mathrm{A}}-\mathrm{n}_{\mathrm{B}} \mathrm{N}_{\mathrm{B}}-\mathrm{b}+\mathrm{a}_{\mathrm{B}}}{2+\mathrm{a}_{\mathrm{A}}+\mathrm{a}_{\mathrm{B}}}, 0\right\} .
$$

The six equations and the six unknowns determine an equilibrium in which the minority population splits up between the two countries.

\subsection{The equilibrium for residence in country A only}

Assume now that the population we are talking about is confined to live in country A only, i.e.

(9) $\quad \mathrm{P}_{\mathrm{A}}=1$.

The reason for this may be migration restrictions, or the fact that country B does not exist. The equilibrium is described by $\mathrm{P}_{\mathrm{A}}, \mathrm{N}_{\mathrm{A}}$ and $\mathrm{n}_{\mathrm{A}}$, which can be calculated from equations (4), (6) and (9).

\subsection{The transition process}

The goal of this paper is to analyze the transition process from a one-country residence to a two-country residence equilibrium. Imagine that an exogenous shock all of a sudden allows people to migrate from A to B. The shock may be the foundation of a state or the removal of migration barriers. The transition process works as follows: In every period, people first decide whether to stay in A or whether to move. If the utility in country B is higher than the utility in A, the individual moves. After that, a re- 
structuring of communities takes place, such that the minimum size of every community is $\gamma$ again, and no one has an incentive to move to another community within his country of residence. Of course, the restructuring of communities changes utilities in both countries, so that in the next period, there may be migration again.

To see how many people migrate and who migrates, we show that if person $\mathrm{i}$ with $x^{i}$ wants to migrate, any person $\mathrm{j}$ with $\mathrm{x}^{\mathrm{j}}, \mathrm{x}^{\mathrm{j}}>\mathrm{x}^{\mathrm{i}}$ also wants to migrate. To do so, we distinguish four cases and calculate the difference in the utility difference of being in $B$ or in $A$ for $i$ and $j$. If this term is negative, the utility difference is higher for $\mathrm{j}$, thus, if i migrates, $\mathrm{j}$ migrates, too.

$$
\mathrm{x}^{\mathrm{i}} \text { and } \mathrm{x}^{\mathrm{j}} \text { live in the same community, } \overline{\mathrm{x}_{\mathrm{A}}^{\mathrm{i}}}=\overline{\mathrm{x}}_{\mathrm{A}}^{\mathrm{j}} \text {, with } \overline{\mathrm{x}}_{\mathrm{A}}^{\mathrm{i}}<\mathrm{x}^{\mathrm{i}}<\mathrm{x}^{\mathrm{j}}
$$

$$
\left(U_{B}^{i}-U_{A}^{i}\right)-\left(U_{B}^{j}-U_{A}^{j}\right)=\left(2+a_{A}+a_{B}\right)\left(x^{i}-x^{j}\right)<0
$$

$$
\mathrm{x}^{\mathrm{i}} \text { and } \mathrm{x}^{\mathrm{j}} \text { live in the same community, } \overline{\mathrm{x}}_{\mathrm{A}}^{\mathrm{i}}=\overline{\mathrm{x}}_{\mathrm{A}} \text {, with } \mathrm{x}^{\mathrm{i}}<\mathrm{x}^{\mathrm{j}}<\overline{\mathrm{x}}_{\mathrm{A}}^{\mathrm{i}}
$$

$$
\left(U_{B}^{i}-U_{A}^{i}\right)-\left(U_{B}^{j}-U_{A}^{j}\right)=\left(a_{A}+a_{B}\right)\left(x^{i}-x^{j}\right)<0
$$

$$
x^{i} \text { and } x^{j} \text { live in the same community, } \bar{x}_{A}^{1}=\bar{x}_{A}^{j} \text {, with } x^{i}<\bar{x}_{A}^{1}<x^{j}
$$

$$
\left(U_{B}^{i}-U_{A}^{i}\right)-\left(U_{B}^{j}-U_{A}^{j}\right)=\left(a_{A}+a_{B}\right)\left(x^{i}-x^{j}\right)-2\left(x^{j}-\bar{x}_{A}{ }^{i}\right)<0
$$

$$
\begin{aligned}
& x^{i} \text { and } x^{j} \text { live in a different community, } \bar{x}_{A}^{1}<\bar{x}_{A}^{j} \\
& \left(U_{B}^{i}-U_{A}^{i}\right)-\left(U_{B}^{j}-U_{A}^{j}\right)=\left(1+a_{A}+a_{B}\right)\left(x^{i}-x^{j}\right)+\left|x^{i}-\bar{x}_{A}{ }^{i}\right|-\left|x^{j}-\bar{x}_{A}{ }^{j}\right|<0^{3}
\end{aligned}
$$

The utility difference is larger in the first than in the second case, because in addition to the fact that country $B$ fits $\mathrm{j}$ better than $\mathrm{i}, \mathrm{j}$ improves his position in the community relative to $i$. Prior to migration, $j$ is more distant to the center of their community than $\mathrm{i}$, and after migration, he is closer. Generally, people who live to the right of their community center rather migrate than those who live to the left of it, because their loss due to an increased distance to their community center is smaller.

To calculate the migration rate, we have to find an $\mathrm{x}_{\mathrm{t}}^{\mathrm{i}} *$ which is indifferent between staying and moving in period t. The first section on the line where we look for $\mathrm{x}_{\mathrm{t}} \mathrm{i}^{*}$ is to the right of the community center which is the farthest on the right in country A. $\mathrm{x}_{\mathrm{t}}^{\mathrm{i}}$ * is given by

$$
\mathrm{x}_{\mathrm{t}}^{\mathrm{i} *}=\frac{\overline{\mathrm{x}}_{\mathrm{A}, \mathrm{t}-1}^{\mathrm{i}}+\overline{\mathrm{x}}_{\mathrm{B}, \mathrm{t}-1}^{\mathrm{i}}-\mathrm{b}+\mathrm{a}_{\mathrm{B}}}{2+\mathrm{a}_{\mathrm{A}}+\mathrm{a}_{\mathrm{B}}} \quad\left(\text { for } \mathrm{x}_{\mathrm{t}}^{\mathrm{i}} *>\overline{\mathrm{x}}_{\mathrm{A}, \mathrm{t}-1}\right)
$$

\footnotetext{
${ }^{3}$ Here, we get four different cases again, which we solve with an upper estimate.

(1) For $\bar{x}_{A}^{i}<x^{i}$ and $\bar{x}_{A}^{j}<x^{j},\left(U_{B}^{i}-U_{A}^{i}\right)-\left(U_{B}^{j}-U_{A}^{j}\right) \leq\left(1 / 2+a_{A}+a_{B}\right)\left(x^{i}-x^{j}\right)<0$.

(2) For $\bar{x}_{\mathrm{A}}^{\mathrm{i}}>\mathrm{x}^{\mathrm{i}}$ and $\overline{\mathrm{x}}_{\mathrm{A}}^{\mathrm{j}}>\mathrm{x}^{\mathrm{j}},\left(\mathrm{U}_{\mathrm{B}}^{\mathrm{i}}-\mathrm{U}_{\mathrm{A}}^{\mathrm{i}}\right)-\left(\mathrm{U}_{\mathrm{B}}^{\mathrm{j}}-\mathrm{U}_{\mathrm{A}}^{\mathrm{j}}\right)=\left(\mathrm{a}_{\mathrm{A}}+\mathrm{a}_{\mathrm{B}}\right)\left(\mathrm{x}^{\mathrm{i}}-\mathrm{x}^{\mathrm{j}}\right)-\mathrm{n}_{\mathrm{A}}<0$.

(3) For $\bar{x}_{\mathrm{A}}^{\mathrm{i}}<\mathrm{x}^{\mathrm{i}}$ and $\overline{\mathrm{x}}_{\mathrm{A}}^{\mathrm{j}}>\mathrm{x}^{\mathrm{j}},\left(\mathrm{U}_{\mathrm{B}}^{\mathrm{i}}-\mathrm{U}_{\mathrm{A}}^{\mathrm{i}}\right)-\left(\mathrm{U}_{\mathrm{B}}^{\mathrm{j}}-\mathrm{U}_{\mathrm{A}}^{\mathrm{j}}\right) \leq\left(\mathrm{a}_{\mathrm{A}}+\mathrm{a}_{\mathrm{B}}\right)\left(\mathrm{x}^{\mathrm{i}}-\mathrm{x}^{\mathrm{j}}\right)<0$.

(4) For $\bar{x}_{A}^{1}<x^{i}$ and $\bar{x}_{A}^{j}>x^{j},\left(U_{B}^{i}-U_{A}^{i}\right)-\left(U_{B}^{j}-U_{A}^{j}\right) \leq\left(a_{A}+a_{B}\right)\left(x^{i}-x^{j}\right)<0$
} 
using the locations of the community centers of the previous period, $t-1$. If $x_{t}^{i} *$ is not within the section in which we were looking for the solution, we conclude that everybody in that section migrates, and look for $\mathrm{x}_{\mathrm{t}}^{\mathrm{i}} *$ in the section to the left of the community center which is the farthest on the right in country A. Here, $\mathrm{x}_{\mathrm{t}}^{\mathrm{i}} *$ is given by

$$
\mathrm{x}_{\mathrm{t}}^{\mathrm{i}} *=\frac{-\overline{\mathrm{x}}_{\mathrm{A}, \mathrm{t}-1}^{\mathrm{i}}+\overline{\mathrm{x}}_{\mathrm{B}, \mathrm{t}-1}^{\mathrm{i}}-\mathrm{b}+\mathrm{a}_{\mathrm{B}}}{\mathrm{a}_{\mathrm{A}}+\mathrm{a}_{\mathrm{B}}} \quad\left(\text { for } \mathrm{x}_{\mathrm{t}}^{\mathrm{i}} *<\overline{\mathrm{x}}_{\mathrm{A}, \mathrm{t}-1}\right) .
$$

Again, if $\mathrm{x}_{\mathrm{t}}^{\mathrm{i}} *$ is not within the section in which we were looking for the solution, we conclude that everybody in that section migrates. So we look for $\mathrm{x}_{\mathrm{t}}^{\mathrm{i}} *$ in the section to the right of the community center which is the farthest but one on the right in country A, using formula (10). We continue like this until we get an interior solution.

After migration, the process of community restructuring takes place. Due to migration, there will be either new communities in country $\mathrm{B}$, or the center of the community on the left border of country B moves farther to the left. In any case, the situation in country B will change in a way that increases the utility of living in B for those who stayed in A. This is what may induce migration in period $t+1$. However, the situation in A also changes, and not necessarily to the worse for the marginal inhabitant.

Figure 1 is an example to illustrate the migration process. Period 1 depicts the old equilibrium, and in period 2 migration starts. The migration rate is at its maximum in period 2 and decreases quickly. The decline is not constant. In period 9, migration is even higher than in 8 , because in period 8 , the number of communities in A decreased by 1 , whereas the number of communities in B increased. The smaller $\gamma$, the smoother is the transition process. The higher $b$, the larger is the share of the population residing in country $\mathrm{B}$ in the new equilibrium.

One assumption we make and which might seem problematic is that people decide completely on their own what to do, without taking others' decisions into account. In a framework in which being located among others with similar preferences is so important, this is somewhat paradox. We do not consider complete ignorance about others' actions as realistic. However, we take it as a benchmark to highlight the transition from one steady-state to another. The opposite benchmark, namely complete knowledge about what others do, would complete the transition to a new equilibrium in one period. Looking at the time series for migration waves that actually took place, it seems that the "complete ignorance" benchmark is closer to reality than the "complete knowledge" benchmark. 


\section{Ethnic German migration: A Case Study}

\subsection{General features of ethnic German migration in the 1990s}

In the next two sections we look at a case for which the model should work, namely ethnic German migration from Eastern Europe and the former Soviet Union to Germany. In this section, we present some general facts about this migration wave. Then we go on comparing the features of the migration wave with the features of the model presented in the last section.

Since emigration from the Eastern European countries and the former Soviet Union has become possible through Michail Gorbatchev's reform policy, about 2.8 Mio ethnic Germans migrated to Germany. Table 1 gives the number of immigrants per year from 1987 to 2000, in total and split up in the main countries of origin, Poland, Romania, Russia, and Kazakhstan. In the beginning, most immigrants came from the two Eastern European countries, however, since 1991, the overwhelming majority is from the CIS countries.

One may ask how people who consider themselves to be of German nationality come to live in Eastern Europe and Asia. For ethnic Germans in Poland, the reason is a border shift, namely the West shift of Poland after World War II. Most ethnic Germans, however, are the descendants of migrants. In former centuries, Russian, Hungarian, and Austrian rulers attracted German farmers in order to civilize empty land. Tempting offers like tax reductions, relief from the army, and warranty of extensive autonomous rights induced large migration waves of German farmers to the Banat and Transylvania, which are now part of Romania, and to regions around St. Petersburg, the Volga, and the Black Sea, which all later on became part of the Soviet Union. The German villages that were found in these areas remained separate from the native population for centuries. Due to the right of self-governance, they did not mix with others, and thus kept their national German identity.

The right to immigrate to Germany and to obtain German citizenship for people of German ethnicity is guaranteed in the German basic law ( 1116$)$. The details are settled in the Bundesvertriebenengesetz (BVFG). The legal status of persons of German descent is called "affiliation to the German people" (deutsche Volkszuge- 
hörigkeit), which entitles them to get German citizenship in case they immigrate to Germany. ${ }^{4}$

Since July 1990, a person can only enter Germany after he has been given the status of an "Aussiedler" (ethnic German) before. The number of applicants is given in the last column of table 1. The application procedure involves several steps. The application is submitted at an embassy in the country of origin. The federal administration office in Cologne checks whether it approves the application. Since 1994, it is necessary to pass a German language test to be accepted..$^{5}$ In addition to that, ethnic Germans who do not come from the former Soviet Union have to prove that they suffered from discrimination due to their nationality. After the federl administration office approved the application, it distributes all applicants on the 16 German Bundesländer (federal states). The Bundesländer check whether they agree to the approval. Since 1994, the maximum number of approvals per year has been restricted to about 200,000 from 1994 to 1999 and to about 100,000 since $2000 .{ }^{6}$ This may mean that if the number of applicants is too high, the application procedure just takes a longer time, as such creating a waiting list for immigration. If we compare the time series in figure 2 with the legal restrictions, it seems that this restriction was indeed binding for 1994 and 1995, but not afterwards. Even before 1994, there may have been an unofficial restriction on the number of immigrants per year through the duration of the applications to be approved.

Once an ethnic German passed these barriers, he may enter Germany and become a citizen. He may bring a spouse, parents, and children who are also entitled to get citizenship. He also qualifies for generous financial support. One example are oldage pensions: Pensioners who come to Germany are entitled to an old-age pension which is equivalent to the pension they would have got if they had been working in the same profession and for the same time in Germany. Other examples are rent subsidies or language courses.

\subsection{Features of the model versus stylized facts of ethnic German migration}

\footnotetext{
${ }^{4}$ See Brubaker (1998) and Kurthen (1995) for a discussion of the German concept of citizenship and its historical roots.

${ }^{5}$ The language test is held at the German embassy closest to the applicant's residence. It is an oral examination. About $30 \%$ of applicants fail. This does not mean that they may not come to Germany: If someone else in their family passes the test, this person may bring him as a relative.

${ }^{6}$ From 1994 to 1999 , the number was restricted to the average of the number of immigrants in 1992 and 1993. From 2000 onwards, it is restricted to the number in 1999. In both cases, the numbers may be exceeded by $10 \%$.
} 
Although ethnic Germans form a huge migration wave, data on it are rare. About 400 ethnic Germans are questioned for the immigration wave of the German Socioeconomic Panel (GSOEP). Bauer and Zimmermann (1997a, 1997b) use these data in order to study their assimilation on the German labor market and the role of ethnic networks. They show that having help from friends and relatives in Germany increases wages considerably, which means that networks or community ties in the new country not only reduce psychic costs of migration, but also increase its pecuniary benefit. Not surprisingly, in our data we find that having relatives in Germany and expecting to get assistance from them increases the propensity to migrate.

The data we use consists of three data sets collected by the Osteuropa-Institut in Munich. The first one, which we label as (1), is from a survey conducted on 879 ethnic German immigrants from the former Soviet Union. The interviews were done in two transition camps (Grenzübergangslager) in Germany from October 1989 to March 1990. The respondents entered Germany in late 1989 and early 1990. This sample is not random with respect to age and sex, because interviewers were asked to have a certain number of respondents in each age and sex group. The second data set, (2), which has 1,013 observations, was collected in six traditional settlement areas of ethnic Germans, three of them in Russia, three of them in Kazakhstan in April and May $1991 .^{7}$ The third data set, (3), has 1520 observations. The interviews were conducted in the Nowosibirsk area (Russia) and the Kustanaj area (Kazakhstan) from June to August 1994. Note that all the data is only on ethnic Germans from the former Soviet Union. Equivalent data on Eastern Europe is not available.

We want to see whether the features of the migration process described in the model can also be found in the data. First, communities should migrate one after the other, i.e. migrants should not come randomly from all existing communities. Second, we should observe those with the strongest ties to country B out of the remaining population in country A to migrate. Third, for those who do not come immediately, the fact that there are already communities in country B close to their own location on the line should be decisive for migration. Finally, the strength of national ties toward country B among newcomers from country A should diminish over time. We will check each of these points in turn.

Concerning the fact that communities migrate one after the other, we can only use data set (1) to find evidence. In data sets (2) and (3), only six or two areas, re-

\footnotetext{
${ }^{7}$ Data sets (1) and (2) are described in more detail in Dietz (1995), pp. 178.
} 
spectively, have been investigated, so that the number of communities is - apart from not being random - by far too small to draw any conclusions from. In data set (1), the new arrivers are asked what percentage of people had already left their village. $25.2 \%$ of respondents say that more than $50 \%$ of the German population in their town of residence in the former Soviet Union had already left for Germany, and 15.3\% say that more than $70 \%$ had already left. This was at a point in time when the emigration of ethnic Germans from the former Soviet Union only just started, as can be seen in figure 2. Still, a number of cities already experienced migration rates that were by far higher than $50 \%$.

In our model, it is always those located on the right end in country A who migrate, i.e. those who feel the most attached to country B relative to A among all country A residents of the population. To check whether this is true for ethnic German migration, we make three comparisons, using the three data sets. First, we compare all observations from data set (1) with all observations from data set (2). In the first data set, we have only early migrants; in the second one, respondents were still in Russia or Kazakhstan in 1991. So we compare very early movers with those who stay or who migrate late. Second, we split up those who are in data set (2) according to whether they have applied for immigration to Germany or not (and possibly already have got an approval), which we take as the most precise measure we have for whether they intend to migrate in the near future or not. Third, we repeat the exercise including observations from data set (3). The reason to do the analysis for data set (2) separately is the greater number of variables we have at choice in that data set. For a complete list of all variables we use, including their mean and standard deviation, separated by data set, see table 2. According to our model, we have to get a significant impact of measures for the degree to which someone is of German nationality on migration or the intention to migrate, respectively, although we look at three different samples. Also, if someone is close to a community in Germany, he should be more willing to migrate. Figure 3 illustrates where, according to our model, the subsamples of the population represented in the three different data sets are located on the Hotelling line. We cannot explicitly include community ties into our estimations. Yet, we correct standard errors for clustering on villages the respondents live in or come from. This allows the errors to be village-specific.

The results of a probit estimation whether someone is in data set (1) or in data set (2) are in table 3 on the left hand side. The variables, which are supposed to proxy 
ethnicity, are in the middle of the table. Having a German spouse and being member of a religious group typical for ethnic Germans are both highly significant. Having German nationality in your passport and having German as mother language, on the other hand, are insignificant. Maybe those who feel more attached to the German nationality would rather call themselves national Germans, but also are more afraid of discrimination and therefore do not like to have their nationality specified in their passport. ${ }^{8}$ Having German as mother tongue may rather describe the circumstances under which someone grew up than his present inclination towards his German origin.

On the right hand side in table 3, estimations using only data set (2) are presented. In this data set, we have a variable whether someone is member of the Wiedergeburt, and whether someone has relatives in Germany and expects them to help in case of migration. Wiedergeburt (English: "Re-birth") is a union of ethnic Germans, which tried to reestablish the autonomous Volga republic. ${ }^{9}$ The German government heavily supported this idea, mainly because it was seen as a means to stop ethnic Germans from coming to Germany. However, after a promising meeting of Chancellor Helmut Kohl and President Boris Jelzin in November 1991, it soon became clear that the Russian government was not willing to give the Volga areas that were by then inhabited by others into German hands. It is interesting to see that being member of the Wiedergeburt has a positive impact on the propensity to leave.

Including existence and support of family members in Germany into our estimation allows us to check for the third feature we wanted to check. We would expect family members to be located relatively close to each other on the Hotelling line. Thus, having family members in Germany and expecting their support reflects the fact that there is a community in Germany, which is located relatively close to the respondent himself.

Table 4 presents three estimations for the migration intention, using only variables that are in both data sets. First, we do the estimation for the two data sets, separately; in the last column, we estimate them jointly, imposing the same coefficients. Again, having a family in Germany and being relatively German in one's attitudes and way of life has a positive impact on the migration intention.

\footnotetext{
${ }^{8}$ Apart from their citizenship, people in the former Soviet Union also had a nationality. The declaration of nationality in the passport was voluntary.

9 The "autonomous Socialist Soviet Republic of the Volga Germans" was founded in 1924 and dissolved in 1941.
} 
The last feature of our model we wanted to check for in this case study is that the degree to which newcomers are German in their habits and attitudes should decrease over time. In fact, comparing the means of the ethnicity variables for the three data sets in table 2, we see that the percentage that has a German spouse and has German as a mother tongue decreases over the three data sets, while the percentage that has a Russian spouse increases. Table 5 presents some more evidence for the decreasing affiliation to German ethnicity of newly arriving ethnic German immigrants. It plots the percentage of immigrants that proved themselves to be of German ethnicity. The difference between the percentage number given and $100 \%$ are non-German family members. Their share increased from about one quarter in 1993 to three quarters in 2000.

To summarize, we found that some basic features of the model also characterize the migration wave of ethnic Germans in the 1990s. Thus the actual migration wave time series should also look similar to the one predicted by the model. In the next section, we compare the two.

\section{Simulation of the migration time series}

To compare actual and predicted migration time series, we first convert the yearly immigration data presented in table 1 into migration rates. ${ }^{10}$ To do that, we need the size of the base population. The numbers we use are based on the 1992 Census for Romania and the 1999 Census for Kazakhstan, and estimations of the German Federal Government and the minority representations in the respective countries. ${ }^{11}$ The Polish German minority is estimated to consist of 1,200,000 people, the Romanian one of 300,000 people, the Soviet one of 3,000,000 people. The Kazakh part consists of 1,000,000 people, the Russian part of 1,200,000 people, and the Kyrgyz part of 100,000 people. Romania, Kyrgyzstan and Kazakhstan have the highest emigration rates. To calculate $\gamma$, we assume the minimum size of a community to consist of 150,000 people. Thus, the $\gamma$ for the Polish population is 0.125 , and for Romania, it is 0.5. As there are a lot of movements of ethnic Germans across countries within the

\footnotetext{
${ }^{10}$ Note that in our model, the migration rate is not the share of the population in country A that leaves per unit of time, but the share of the total population in country A and B that migrates within one period.

${ }^{11}$ In the last Soviet Census from 1989 (cf. Dietz (1995)), the number of ethnic Germans is about 30\% lower than the numbers we use. Note, however, that the Census only counts those who state that their nationality is German. So people who do not state their true nationality and non-German spouses, who are also entitled to immigrate to Germany, are not included in the Census numbers.
} 
former Soviet Union, in particular from the new-founded nation states to Russia, we take them as one big community with a $\gamma$ of 0.05 . Note that an implicit assumption of this model is that the ethnic German populations from the different Eastern European countries do not mix in Germany, but still consider themselves as different ethnic groups.

In our model, there is a shock before which migration is impossible and after which it is unlimited. In reality, emigration restrictions already loosened in the last years of the existence of the Eastern Block. We assume the first year in which migration was unrestricted to be 1988 for Poland, 1989 for the Soviet Union, and 1990 for Romania. As the migration that took place before already changed the community equilibria, we take the migration from 1987 onwards into account for the starting value of the populations in the country of origin and Germany.

For $\mathrm{a}_{\mathrm{A}}$ and $\mathrm{a}_{\mathrm{B}}$, we assume a value of 0.2 , except for Russia, where we take 0.05 for 1989-1991. This is supposed to reflect the expectation of an autonomous republic. Strong autonomy makes the country a person lives in relatively less important, because it diminishes the country's impact on life. As a proxy for b, we take the difference in GDP growth rates for the country of origin and Germany, divided by 100 . For Russia, Kazakhstan and Kyrgyzstan we take the 3-year-average, because the GDP growth rates are extremely volatile. Allowing for $\mathrm{b}$ to change over time makes return migration possible. In fact, there is return migration in our predicted migration time series, whereas we can never observe this in the data, because we only have data on immigrants to Germany.

Last, we need to introduce the immigration restrictions imposed by Germany in the simulations, i.e. we need a maximum migration rate per country and year. For 1993 onwards, we take the maximum number of immigrants allowed per year and assume that the share of country allowances is equal to the share of actual immigrants that came from this country in the respective year. Before 1993, we do not even have a maximum number. We just know that due to the introduction of the application system in July 1990, there was considerable queuing for immigration. Also, we know that in the beginning of the 1990s, there may still have been some restrictions to emigration in the former Soviet Union. We therefore impose for 1989-1992 the number of actual immigrants as the maximum number of immigrants allowed to enter.

Figures 4-8 present the results. For Poland and Romania, the restrictions imposed on the number of immigrants are never binding. For Russia, Kazakhstan and 
Kyrgyzstan, we present both the results without restrictions (figures 6a, 7a, 8a) and with restrictions (figures $6 b, 7 b, 8 b$ ).

For Poland, we overestimate emigration in 1988. We did not impose a restriction on emigration here, though there probably still was one, so this may explain the difference. From 1989-1992, we slightly underestimate the true emigration rate. If we assume that those who return in our simulations are the same as those who immigrate again later, when the simulated migration rate is higher that the actual one, the differences between the true and the predicted time series may be completely due to the fact that we do observe neither return migration nor the return of return migrants in our data. $^{12}$ In the Romania case, we also slightly underestimate the migration rate until 1992, after which the simulated migration rate is much more volatile than the real one. In 1990, the underestimation may be because we do not take panic migration into account. Yet, we are able to roughly replicate the peak in emigration in 1990 of more than $30 \%$ of the population because of the large $\gamma$ of 0.5 , which comes from the small size of the total population. As the Romanian ethnic German population is by far the smallest one we look at, and as there was already some emigration before 1990, there was not a single community left in Romania in the beginning of 1990. Thus, the community ties, which keep people in the source country in the other cases, did not exist there.

For the CIS countries first have a look at the unrestricted time series. They all have a big peak in 1992, though they behave differently before. Afterward, migration rates diminish to quasi zero by 1996. The peak is later than for the two European countries, because the huge decline in growth rates during transition was later for the CIS countries than for Eastern Europe. Notice that the shapes of the migration waves look very similar to the Eastern European ones. The total number of ethnic German immigrants in 1992 would have been almost 500,000 or twice the amount of actual immigrants.

The restricted time series look very different. For Russia, we overpredict the migration rates of 1996 and 1997. Clearly, the restriction on the yearly number of immigrants did not prevent, but postpone migration. For Kazakhstan and Kyrgyzstan, migration rates in 1996 and 1997 are underestimated. The two countries have another

\footnotetext{
${ }^{12}$ An estimated 200,000 Polish ethnic Germans have a double citizenship. Therefore, they can move between the two countries without them being registered in immigration statistics (Informationen zur politischen Bildung, p. 9, 2000).
} 
peculiarity, namely the foundation of the Kazakh and the Kyrgyz national state. So ethnic Germans, who feel attached to the German and to the Russian, but not towards the Kazakh or Kyrgyz nationality became complete strangers in their country of residence. ${ }^{13}$ We take that into account by adding 0.15 to the parameter $b$ from 1992 onwards. $^{14}$

\section{Summary and Conclusions}

This paper presents a model for the migration process that takes place when a population with dual ethnicity, constrained to live in one country, suddenly has the possibility to live in both national states that are part of their own mixed nationality. There are several examples for migration waves like that: Jews from the Diaspora who came to Israel after the foundation of the State of Israel, migration within the former Soviet Union countries, return migration of guest workers or second generation immigrants and also ethnic German migration in the 1990s.

The model is able to explain two common phenomena about migration, which cannot be covered by simple wage comparisons. First, migration does not always take place if there is a positive wage difference, and it can take place in spite of a negative wage difference. Although wage differences are one parameter of the model, ethnicity and community ties also play a role. If the effect of the latter two is stronger, migration does not take place in the direction of the positive wage difference. Second, the transition process described in the model in case migration gets possible is able to explain the procrastination we observe in migration behavior.

We apply the model for the case of ethnic German migration in the 1990s looking at five countries of origin. We also take immigration restrictions into account. The basic results are that Romanian and Polish immigrants were not affected by the immigration restrictions, whereas the Russian, Kazakh and Kyrgyz immigrants were.

\footnotetext{
${ }^{13}$ Ethnic Germans feel more attached to the Russian than to the Kazakh culture. For example, most ethnic Germans speak Russian, whereas only very few speak Kazakh. In data set (3), respondents living in Kazakhstan are asked in detail about their ties toward Russian, German, and Kazakh. In the sample, $21 \%$ of the respondents say that they speak mostly German within the family, $60 \%$ say that they speak mostly Russian, and $20 \%$ say that they speak both. None of them says that they speak Kazakh. Furthermore, asked about their Kazakh language abilities, 93\% say that they do not speak Kazakh at all or that they understand only a few words.

${ }^{14}$ Instead of a constant, we also tried to add the number of Russian emigrants from Kazakhstan per year and accumulated to the parameter b. In 1989, 6.2 Mio Russians lived in Kazakhstan, who made up for $37 \%$ of the population. By 1996, the Russian population had decreased by $10 \%$, whereas the Kazakh population had increased by almost $20 \%$ Heleniak $(1997,2001)$. The results do not change much, so we do not present them here.
} 
Without immigration restrictions, the number of ethnic German immigrants to Germany would have peaked in 1992 at about 500,000 immigrants, and would have shrunk to more or less zero in the end of the 1990s. Immigration restrictions did not prevent, but postpone migration.

\section{$\underline{\text { 6. Literature }}$}

Alesina, Alberto and Enrico Spolaore (1997): On the Number and Size of Nations, Quarterly Journal of Economics 113, 1027-1056.

Baaden, Andreas (1997): Aussiedler-Migration: Historische und aktuelle Entwicklungen, Berlin Verlag, Berlin.

Bauer, Thomas and Klaus F. Zimmermann (1997a): Unemployment and Wages of Ethnic Germans, The Quarterly Review of Economics and Finance 37, 361-377.

---(1997b): Network migration of Ethnic Germans, International Migration Review 31(1), 143-149.

Bolton, Patrick, Gérard Roland and Enrico Spolaore (1996): Economic Theories of the Break-up and Integration of Nations, European Economic Review 40, 697-705.

Borjas, George J. (1995): Ethnicity, Neighborhoods, and Human-Capital Externalities, American Economic Review 85(3), 365-390.

Brubaker, Rogers (1998): Migrations of Ethnic Unmixing in the "New Europe", International Migration Review 32(4), 1047-1065.

Burda, Michael C. (1993): The determinants of East-West German Migration: Some First Results, European Economic Review 37, 452-461.

---(1995): Migration and the Option Value of Waiting, The Economic and Social Review 27(1), 1-19.

Burda, Michael C., Wolfgang Härdle, Marlene Müller and Axel Werwatz (1998): Semiparametric Analysis of German East-West Migration Intentions: Facts and Theory, Journal of Applied Econometrics 13, 525-541.

Dietz, Barabara (1995): Zwischen Anpassung und Autonomie: Rußlanddeutsche in der vormaligen Sowjetunion und in der Bundesrepublik Deutschland, Duncker \& Humblot, Berlin.

Epstein, Gil and Arye L. Hillman (1998): Herd Effects and Migration, CEPR Discussion Paper 1811.

Heleniak, Tim (2001): The End of an Empire: Migration and the Changing Nationality Composition of the Soviet Successor States in: Rainer Münz und Rainer Ohliger: Diasporas and Ethnic Migrants: Germany, Israel and Post-Soviet Space in Comparative Perspective, Oxford: Frank Cass.

---(1997): The Changing Nationality Composition of the Central Asian and Transcaucasian States, Post-Soviet Geography and Economics 38(6), 357-378.

Hatton, Timothy (1995): A Model of U.K. Emigration, 1870-1913, The Review of Economics and Statistics 77(3), 407-415. 
Informationen zur politischen Bildung Nr. 267: Aussiedler (2000)

Kurthen, Hermann (1995): Germany at the Crossroads: National Identity and the Challenges of Immigration, International Migration Review 29(4), 914-938.

O'Connell, Paul G. J. (1997): Migration under uncertainty: "Try your luck" or "Wait and see", Journal of Regional Science 37(2), 331-374. 
$\underline{\text { Tables and Figures }}$

Table 1: Number of ethnic German immigrants

\begin{tabular}{cccccccc}
\hline Year & FSU & Kazakhstan & Russia & Poland & Romania & Total & $\begin{array}{c}\text { Appli- } \\
\text { cations }\end{array}$ \\
\hline 1987 & 14,488 & & & 48,419 & 13,990 & 78,523 & \\
1988 & 47,572 & & & 140,226 & 12,902 & 202,673 & \\
1989 & 98,134 & & & 250,340 & 23,387 & 377,055 & \\
1990 & 147,455 & & & 113,253 & 107,189 & 397,075 & 128,844 \\
1991 & 147,320 & & & 40,129 & 32,178 & 221,995 & 561,352 \\
1992 & 195,576 & 114,382 & 55,875 & 17,742 & 16,146 & 230,565 & 402,375 \\
1993 & 207,347 & 113,288 & 67,365 & 5,431 & 5,811 & 218,888 & 241,178 \\
1994 & 213,214 & 121,517 & 68,397 & 2,440 & 6,615 & 222,591 & 237,291 \\
1995 & 209,409 & 117,148 & 71,685 & 1,677 & 6,519 & 217,898 & 260,556 \\
1996 & 172,181 & 92,125 & 63,311 & 1,175 & 4,284 & 177,751 & 168,758 \\
1997 & 131,895 & 73,967 & 47,055 & 687 & 1,777 & 134,419 & 147,577 \\
1998 & 101,550 & 51,132 & 41,054 & 488 & 1,005 & 103,080 & 100,421 \\
1999 & 103,599 & 49,391 & 45,951 & 428 & 855 & 104,916 & 117,101 \\
2000 & 94,558 & 45,657 & 41,478 & 484 & 547 & 95,615 & 106,895 \\
\hline
\end{tabular}

Source: German Statistical Yearbook, table 6.40, several years, Baaden (1997), p. 20, Federal Administration Office Cologne, applications in 1990 only for July-December. 
Table 2: Description of variables

\begin{tabular}{|c|c|c|c|c|}
\hline \multicolumn{3}{|c|}{$\begin{array}{c}\text { Mean (standard } \\
\text { deviation) of variables }\end{array}$} & \multirow[t]{2}{*}{ Variable name } & \multirow[t]{2}{*}{ Description of variable } \\
\hline$(1)$ & $(2)$ & (3) & & \\
\hline $\begin{array}{l}41.4 \\
(14.2)\end{array}$ & $\begin{array}{c}36.6 \\
(11.8)\end{array}$ & $\begin{array}{l}32.9 \\
(11.9)\end{array}$ & Age90 & Age of the respondent in 1990 \\
\hline $\begin{array}{c}1916 \\
(1330)\end{array}$ & $\begin{array}{l}1479 \\
(971)\end{array}$ & $\begin{array}{l}1224 \\
(838)\end{array}$ & Age90sq & Age squared of the respondent in 1990 \\
\hline $\begin{array}{c}2.80 \\
(1.24)\end{array}$ & $\begin{array}{c}3.52 \\
(1.23)\end{array}$ & $\begin{array}{l}3.25 \\
(1.10)\end{array}$ & Education & $\begin{array}{l}\text { Levels of education degrees in the Soviet } \\
\text { system, increasing from } 0-6\end{array}$ \\
\hline $\begin{array}{l}.077 \\
(.267) \\
\end{array}$ & $\begin{array}{l}.291 \\
(.454) \\
\end{array}$ & $\begin{array}{l}.302 \\
(.459) \\
\end{array}$ & Married Russian & $\begin{array}{l}\text { Married to a person who is not of German } \\
\text { nationality }\end{array}$ \\
\hline $\begin{array}{l}.758 \\
(.429) \\
\end{array}$ & $\begin{array}{l}.465 \\
(.499) \\
\end{array}$ & $\begin{array}{l}.477 \\
(.450) \\
\end{array}$ & Married German & Married to a person of German nationality \\
\hline $\begin{array}{l}.660 \\
(.474) \\
\end{array}$ & $\begin{array}{c}.634 \\
(.482) \\
\end{array}$ & $\begin{array}{l}.605 \\
(.489) \\
\end{array}$ & Kids & Dummy for having children \\
\hline $\begin{array}{c}1.49 \\
(1.43)\end{array}$ & $\begin{array}{l}1.21 \\
(1.14)\end{array}$ & $\begin{array}{r}1.09 \\
(1.09)\end{array}$ & Number kids & Number of children \\
\hline $\begin{array}{l}.951 \\
(.216) \\
\end{array}$ & $\begin{array}{l}.909 \\
(.287)\end{array}$ & $\begin{array}{l}.930 \\
(.256)\end{array}$ & German passport & $\begin{array}{l}\text { Having reported "German" as nationality } \\
\text { in your Soviet passport }\end{array}$ \\
\hline $\begin{array}{l}.703 \\
(.457)\end{array}$ & $\begin{array}{l}.600 \\
(.490)\end{array}$ & $\begin{array}{l}.590 \\
(.388)\end{array}$ & Native German & Being German native speaker \\
\hline $\begin{array}{l}.786 \\
(.410)\end{array}$ & $\begin{array}{l}.319 \\
(.466)\end{array}$ & $\begin{array}{l}.535 \\
(.499)\end{array}$ & Religion & $\begin{array}{l}\text { Being member of a church, excluding } \\
\text { Russian orthodox (mainly protestant chur- } \\
\text { ches) }\end{array}$ \\
\hline $\begin{array}{l}.957 \\
(.203)\end{array}$ & $\begin{array}{l}.700 \\
(.459)\end{array}$ & & Know share & $\begin{array}{l}\text { Respondent knows the share of the Ger- } \\
\text { man population in his/her home town }\end{array}$ \\
\hline $\begin{array}{l}.208 \\
(.406)\end{array}$ & $\begin{array}{l}.244 \\
(.430) \\
\end{array}$ & & German share & $\begin{array}{l}\text { Share of German population in home town } \\
\text { is over } 0.5\end{array}$ \\
\hline $\begin{array}{r}.812 \\
(.391) \\
\end{array}$ & $\begin{array}{l}.665 \\
(.472) \\
\end{array}$ & & Election & Respondent goes to elections \\
\hline \multirow[t]{5}{*}{$\begin{array}{l}.503 \\
(.500) \\
\end{array}$} & $\begin{array}{l}.333 \\
(.471) \\
\end{array}$ & & Car & Respondent has a car \\
\hline & $\begin{array}{l}.683 \\
(.466)\end{array}$ & $\begin{array}{l}.796 \\
(.403)\end{array}$ & Relative German & Respondent has relatives in Germany \\
\hline & $\begin{array}{l}.359 \\
(.480)\end{array}$ & & Help relatives & $\begin{array}{l}\text { In case of migration, help from relatives in } \\
\text { Germany is expected }\end{array}$ \\
\hline & $\begin{array}{l}.147 \\
(.354)\end{array}$ & & Wiedergeburt & $\begin{array}{l}\text { Member of Wiedergeburt (union of ethnic } \\
\text { Germans, tried to reestablish the auto- } \\
\text { nomous Volga republic) }\end{array}$ \\
\hline & & & Data (2) & Observation is from data set (2) \\
\hline $\begin{array}{l}.215 \\
(.411)\end{array}$ & $\begin{array}{l}.506 \\
(.500)\end{array}$ & $\begin{array}{l}.665 \\
(.472)\end{array}$ & Russia & Respondent is from Russia \\
\hline
\end{tabular}


Table 3: Early migration and migration intention, probit estimates

\begin{tabular}{|c|rl|rl|}
\hline & \multicolumn{2}{|c|}{$\begin{array}{c}\text { Data set (1) and (2), } \\
\text { Dependent variable: migration }\end{array}$} & \multicolumn{2}{c|}{$\begin{array}{c}\text { Data set (2), Dependent } \\
\text { variable: migration intention }\end{array}$} \\
\hline \hline Age90 & -0.062 & $(3.07)^{* *}$ & 0.014 & $(0.47)$ \\
\hline Age90sq & 0.001 & $(2.78)^{* *}$ & -0.000 & $(0.70)$ \\
\hline Education & -0.255 & $(6.97)^{* *}$ & 0.025 & $(0.56)$ \\
\hline Married & -0.459 & $(3.35)^{* *}$ & 0.220 & $(1.32)$ \\
\hline Kids & 0.004 & $(0.03)$ & 0.134 & $(0.71)$ \\
\hline Number kids & 0.168 & $(2.62)^{* *}$ & -0.153 & $(1.84)$ \\
\hline Married German & 0.701 & $(5.98)^{* *}$ & 0.384 & $(2.08)^{* *}$ \\
\hline German passport & -0.106 & $(0.62)$ & 0.026 & $(0.15)$ \\
\hline Native German & -0.063 & $(0.56)$ & 0.132 & $(0.90)$ \\
\hline Religion & 1.051 & $(8.04)^{* *}$ & 0.656 & $(5.58)^{* *}$ \\
\hline Wiedergeburt & & & 0.630 & $(2.98)$ \\
\hline Know share & 1.453 & $(11.61)^{* *}$ & & \\
\hline German share & -0.642 & $(2.81)^{* *}$ & & \\
\hline Relative German & & & 0.640 & $(3.54)$ \\
\hline Help relatives & & & 0.516 & $(3.49)$ \\
\hline \hline Election & 0.374 & $(3.73)^{* *}$ & \multicolumn{2}{l|}{} \\
\hline Car & 0.221 & $(2.79)^{* *}$ & 0.268 & $(3.39)^{* *}$ \\
\hline Russia & -0.566 & $(2.04)^{*}$ & -0.428 & $(3.74)^{* *}$ \\
\hline Constant & -0.008 & $(0.01)$ & -2.391 & $(4.37)^{* *}$ \\
\hline Observations & 1,890 & & 1,002 & \\
\hline Pseudo R & 0.37 & & 0.23 & \\
\hline
\end{tabular}

Note: Robust z-statistics in parentheses, $*$ significant at $5 \%$ level; ** significant at $1 \%$ level, clustering for villages 
Table 4: Migration intention in 1991 and 1994, probit estimates

\begin{tabular}{|c|rl|rl|rl|}
\hline & \multicolumn{2}{|c|}{ Data set (2) } & \multicolumn{2}{|c|}{ Data set (3) } & \multicolumn{2}{|c|}{ Data sets (2) and (3) } \\
\hline \hline Age90 & 0.013 & $(0.53)$ & -0.004 & $(0.22)$ & -0.015 & $(0.93)$ \\
\hline Age90sq & 0.000 & $(0.64)$ & 0.000 & $(0.28)$ & 0.000 & $(0.52)$ \\
\hline Education & 0.096 & $(1.85)$ & 0.047 & $(1.03)$ & 0.069 & $(1.84)$ \\
\hline Married & 0.212 & $(1.36)$ & -0.353 & $(2.98)^{* *}$ & -0.129 & $(1.20)$ \\
\hline Kids & 0.160 & $(0.90)$ & 0.320 & $(2.46)^{*}$ & 0.279 & $(2.50)^{*}$ \\
\hline Number kids & -0.170 & $(2.22)^{*}$ & -0.094 & $(1.66)$ & -0.110 & $(2.23)^{*}$ \\
\hline \hline Married German & 0.366 & $(1.95)$ & 0.258 & $(2.30)^{*}$ & 0.256 & $(2.34)^{*}$ \\
\hline German passport & 0.061 & $(0.40)$ & 0.021 & $(0.12)$ & -0.001 & $(0.01)$ \\
\hline Native German & 0.142 & $(0.90)$ & 0.593 & $(4.00)^{* *}$ & 0.408 & $(3.37)^{* *}$ \\
\hline Religion & 0.686 & $(5.63)^{* *}$ & 0.409 & $(4.04)^{* *}$ & 0.514 & $(5.91)^{* *}$ \\
\hline \hline Relative German & 0.933 & $(7.10)^{* *}$ & 0.817 & $(6.25)^{* *}$ & 0.885 & $(9.70)^{* *}$ \\
\hline \hline Data set $(2)$ & & & & & -0.510 & $(3.73)^{* *}$ \\
\hline Russia & -0.415 & $(2.70)^{* *}$ & -1.069 & $(7.75)^{* *}$ & -0.825 & $(6.62)^{* *}$ \\
\hline Constant & -2.520 & $(5.42)^{* *}$ & -0.736 & $(1.90)$ & -0.992 & $(2.91)^{* *}$ \\
\hline \hline Observations & 1,008 & & 1,431 & & 2,439 & \\
\hline Pseudo R & 0.19 & & 0.24 & & 0.22 & \\
\hline
\end{tabular}

Note: Robust z-statistics in parentheses, * significant at $5 \%$ level; ** significant at $1 \%$ level, clustering for villages

Table 5: Percentage of total ethnic German immigrants (including family members) that personally proved German ethnicity

\begin{tabular}{|l|llllllll|}
\hline Year & 1993 & 1994 & 1995 & 1996 & 1997 & 1998 & 1999 & 2000 \\
\hline Percentage & 47.08 & 60.92 & 55.44 & 47.68 & 39.71 & 34.05 & 29.49 & 26.34 \\
\hline
\end{tabular}




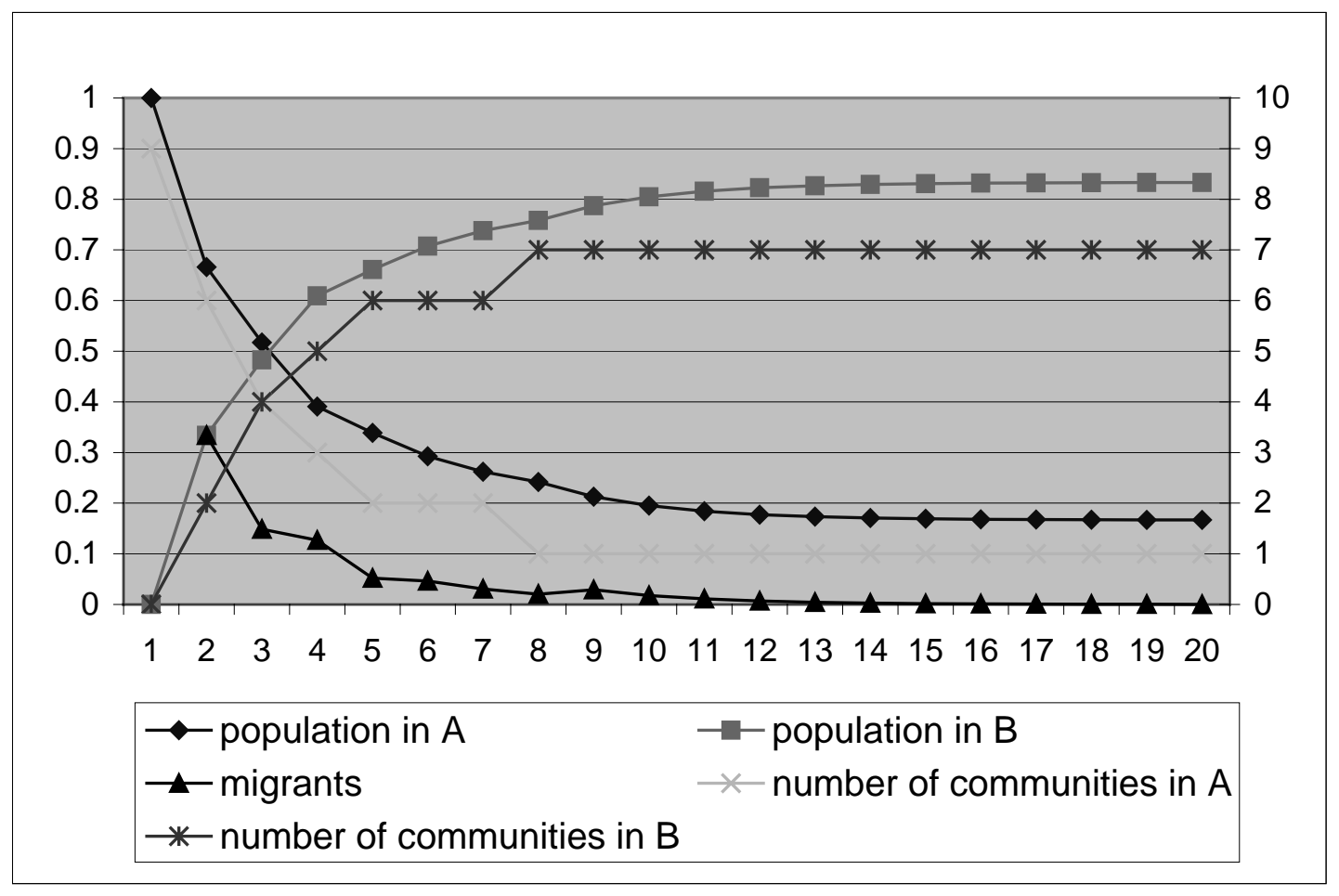

Figure 1: Migration for $\gamma=0.1, a_{A}=a_{B}=0.3, b=0.2$, right scale for number of communities in $\mathrm{A}$ and $\mathrm{B}$

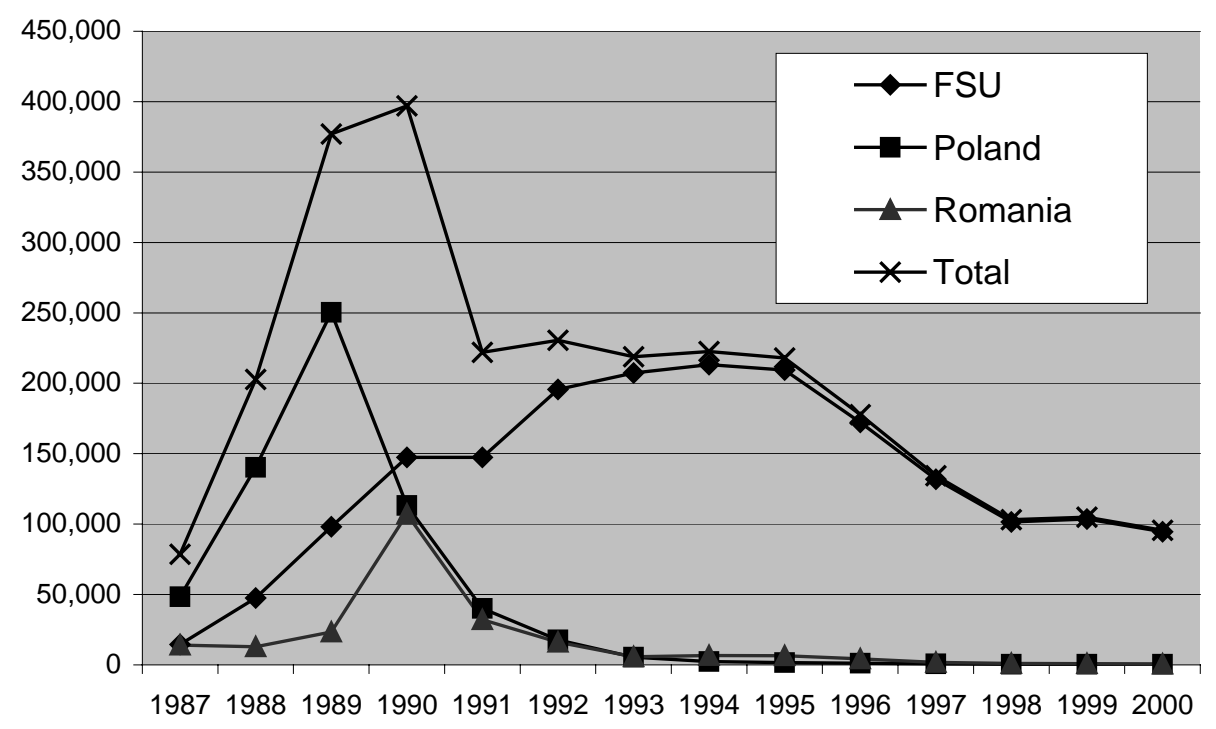

Figure 2: Number of ethnic German immigrants per year, 1987-2000 
(e)

(d)

(a)
(a) data set (1), all respondents migrated by 1990
(b) data set (2), respondents intend to migrate in 1991
(c) data set (2), respondents intend to stay in 1991
(d) data set (3), respondents intend to migrate in 1994
(e) data set (3), respondents intend to stay in 1994

Figure 3: Ideal position on respondents in the three data sets on the Hotelling line

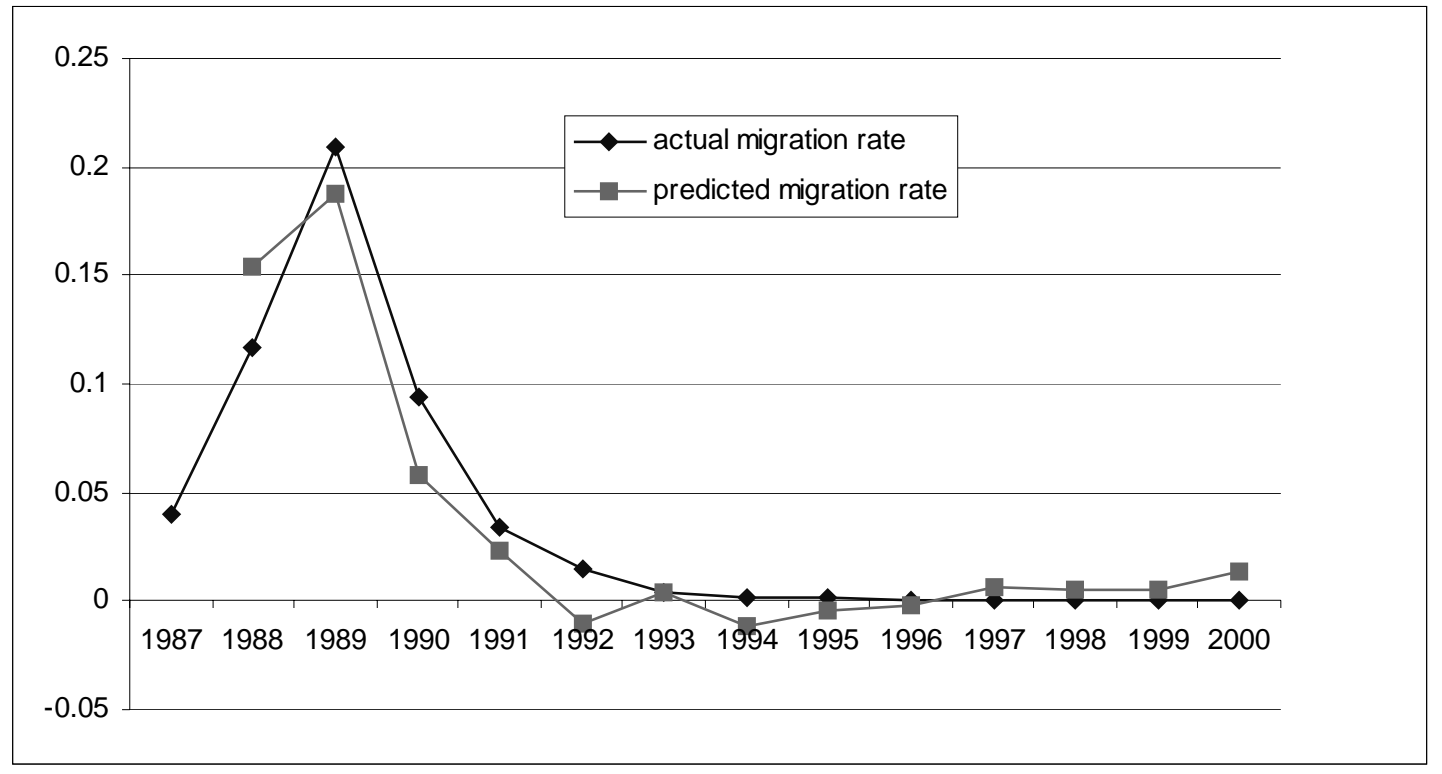

Figure 4: Actual and predicted emigration rate from Poland; $\gamma \approx 0.125$, $\mathrm{a}_{\mathrm{A}}=\mathrm{a}_{\mathrm{B}}=0.2, \mathrm{~b}=$ difference in GDP growth rates $/ 100$ 


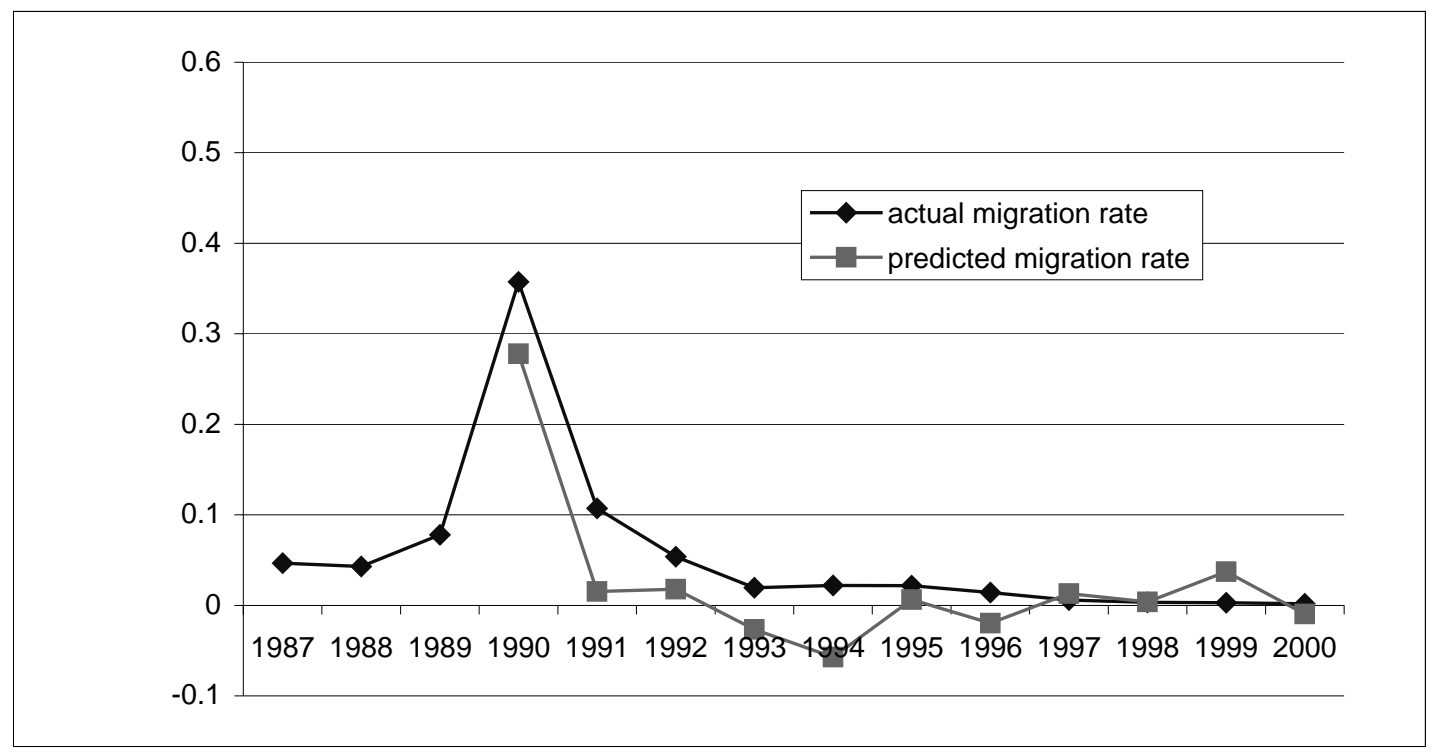

Figure 5: Actual and predicted emigration rate from Romania; $\gamma \approx 0.5$, $\mathrm{a}_{\mathrm{A}}=\mathrm{a}_{\mathrm{B}}=0.2, \mathrm{~b}=$ difference in GDP growth rates $/ 100$

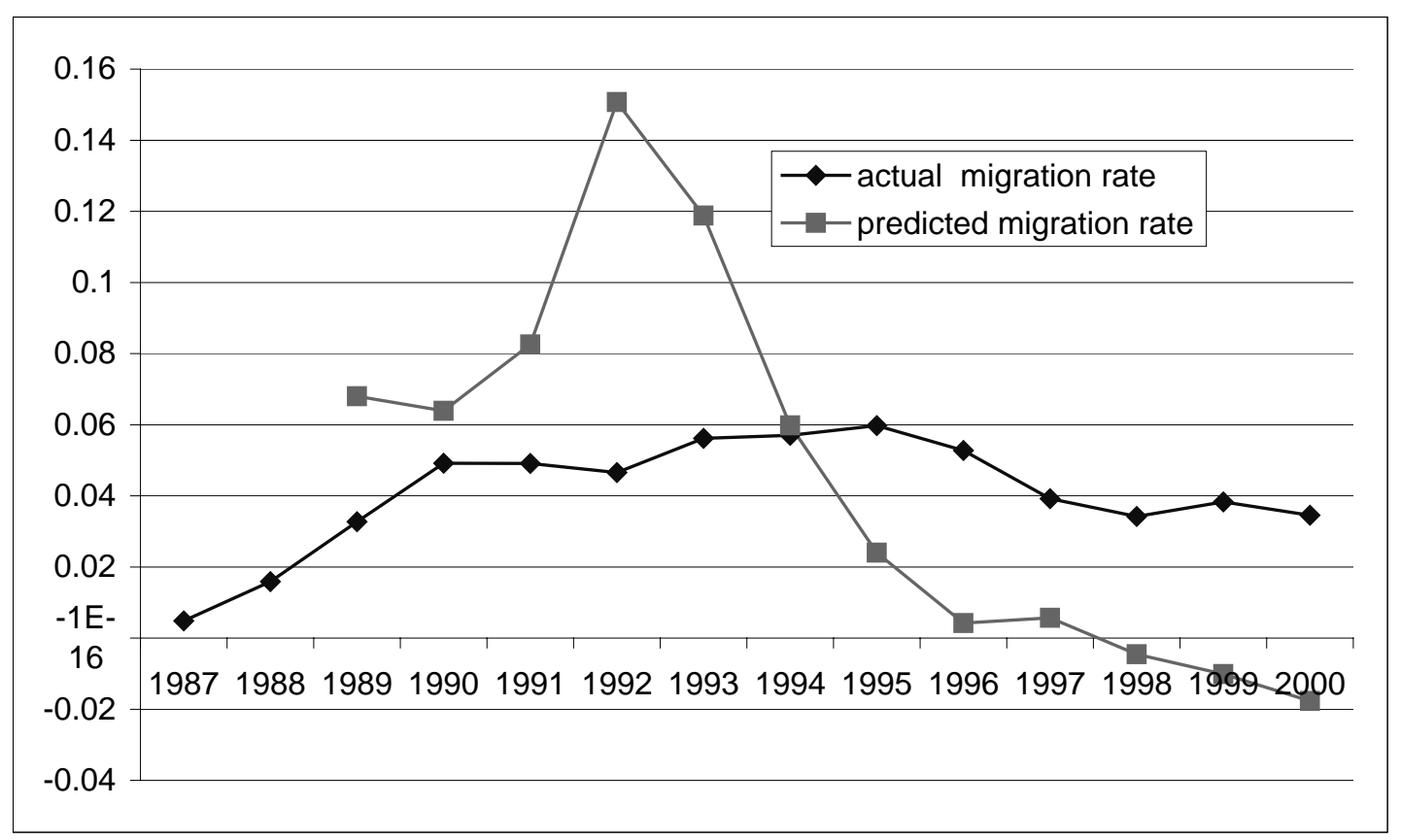

Figure 6a: Actual and predicted unrestricted emigration rate from Russia; $\gamma \approx 0.05, \mathrm{a}_{\mathrm{A}}=0,05(1989-1991), \mathrm{a}_{\mathrm{A}}=0,2(1991-2000), \mathrm{a}_{\mathrm{B}}=0.2$, $\mathrm{b}=$ Three-year average of difference in GDP growth rates/100 


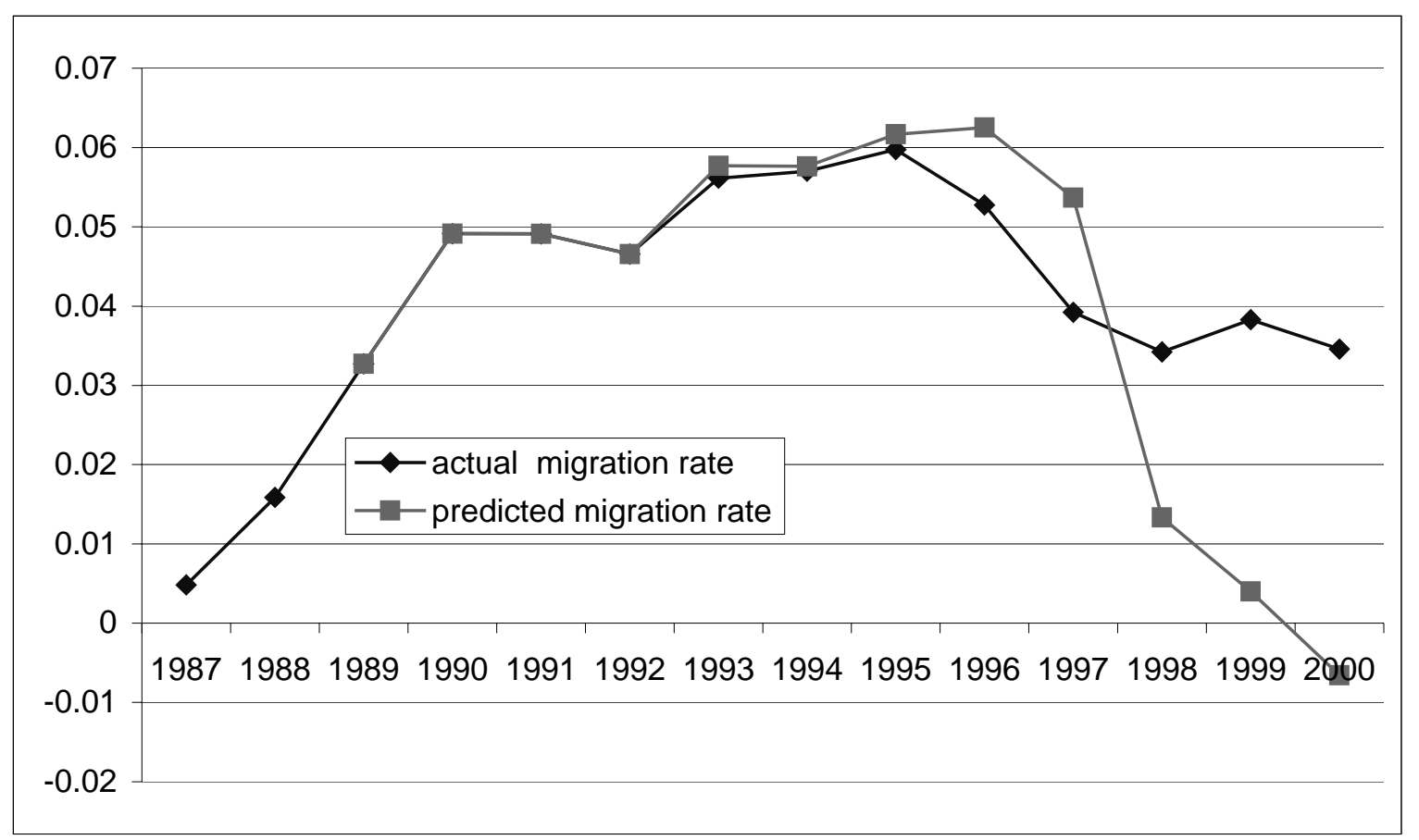

Figure 6b: Actual and predicted restricted emigration rate from Russia; $\gamma$ $\approx 0.05, \mathrm{a}_{\mathrm{A}}=0,05$ (1989-1991), $\mathrm{a}_{\mathrm{A}}=0,2(1991-2000), \mathrm{a}_{\mathrm{B}}=0.2, \mathrm{~b}=$ Threeyear average of difference in GDP growth rates/100

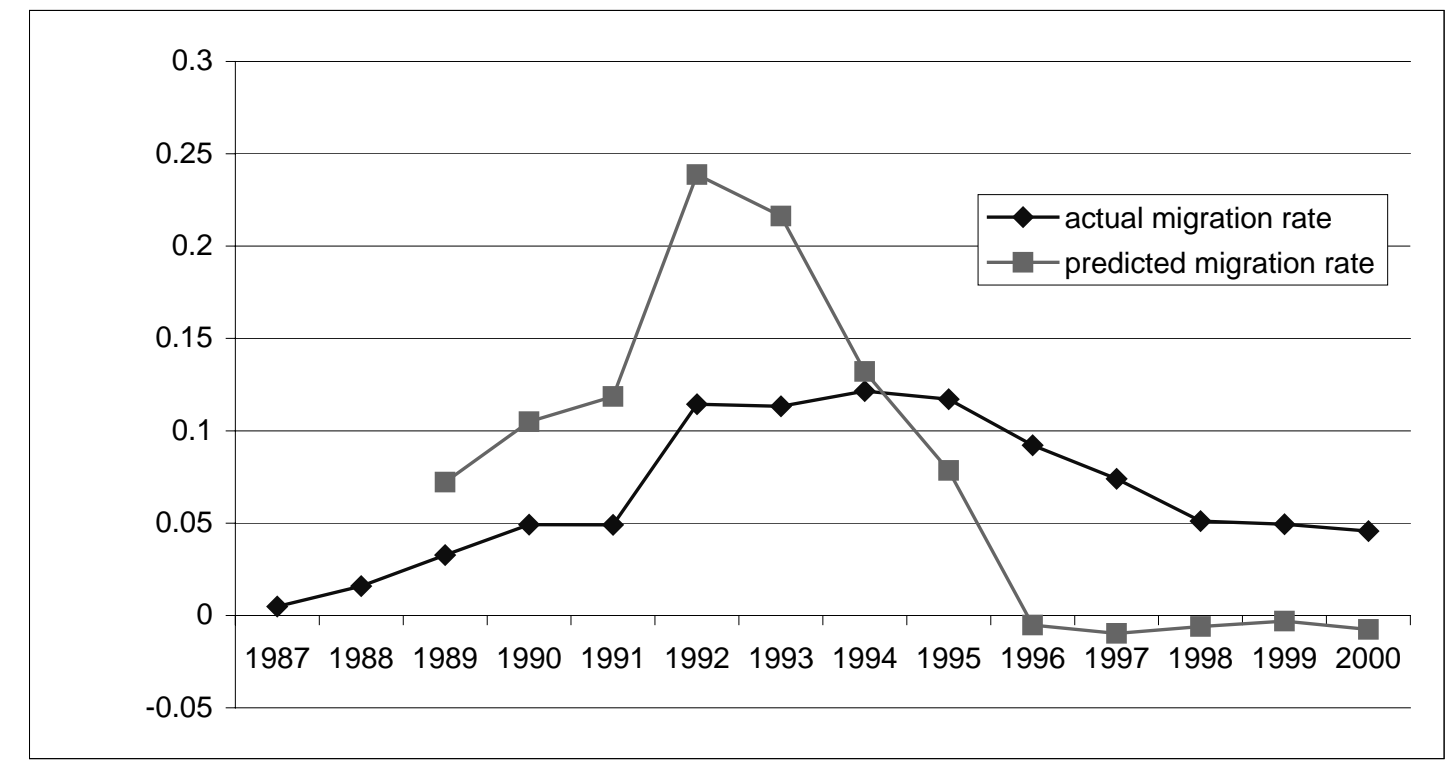

Figure 7a: Actual and predicted unrestricted emigration rate from Kazakhstan; $\gamma \approx 0.05, \mathrm{a}_{\mathrm{A}}=0,2, \mathrm{a}_{\mathrm{B}}=0.2, \mathrm{~b}=0.15$ (since 1992) + three-year average of difference in GDP growth rates/100 


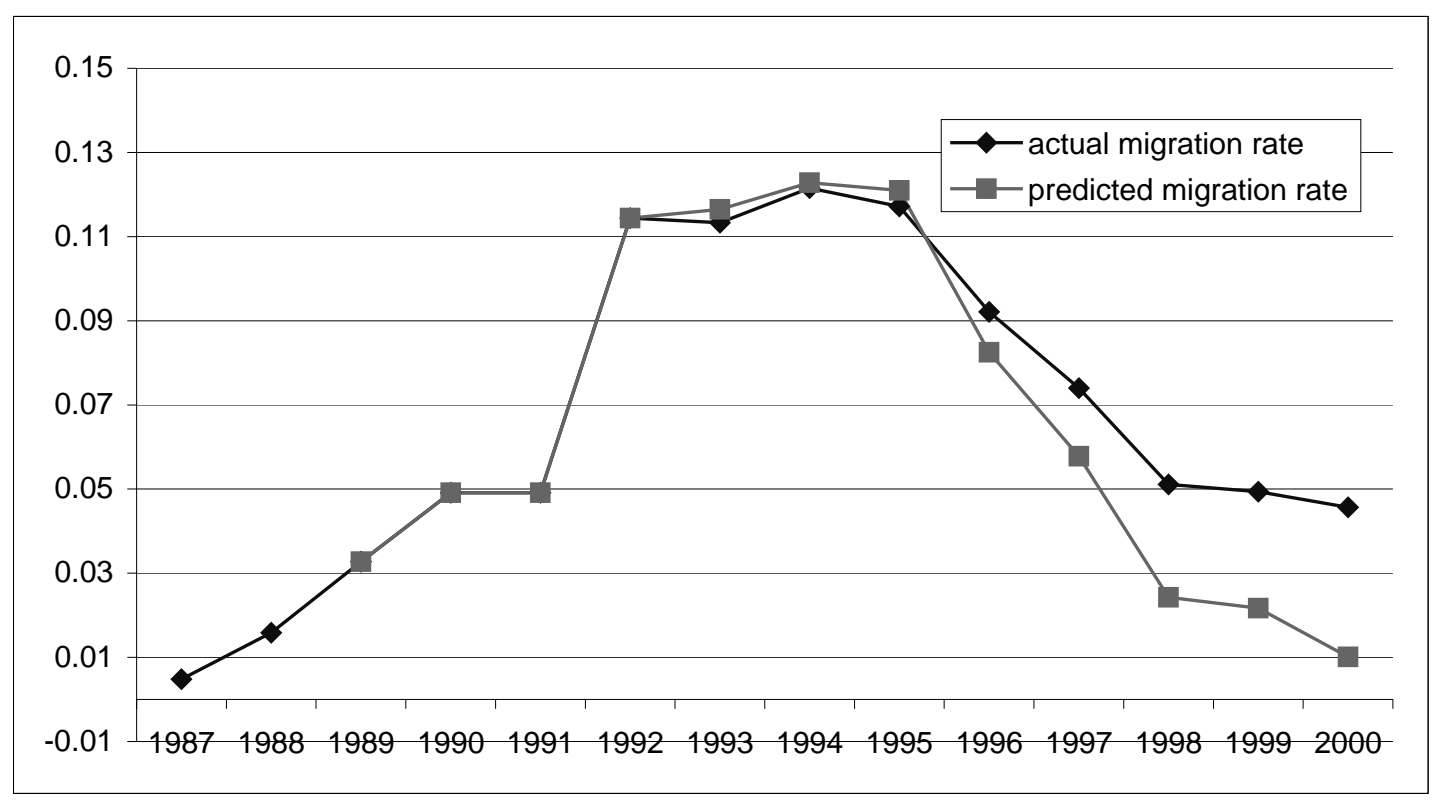

Figure 7b: Actual and predicted restricted emigration rate from Kazakhstan; $\gamma \approx 0.05, \mathrm{a}_{\mathrm{A}}=0,2, \mathrm{a}_{\mathrm{B}}=0.2, \mathrm{~b}=0.15$ (since 1992) + three-year average of difference in GDP growth rates/100

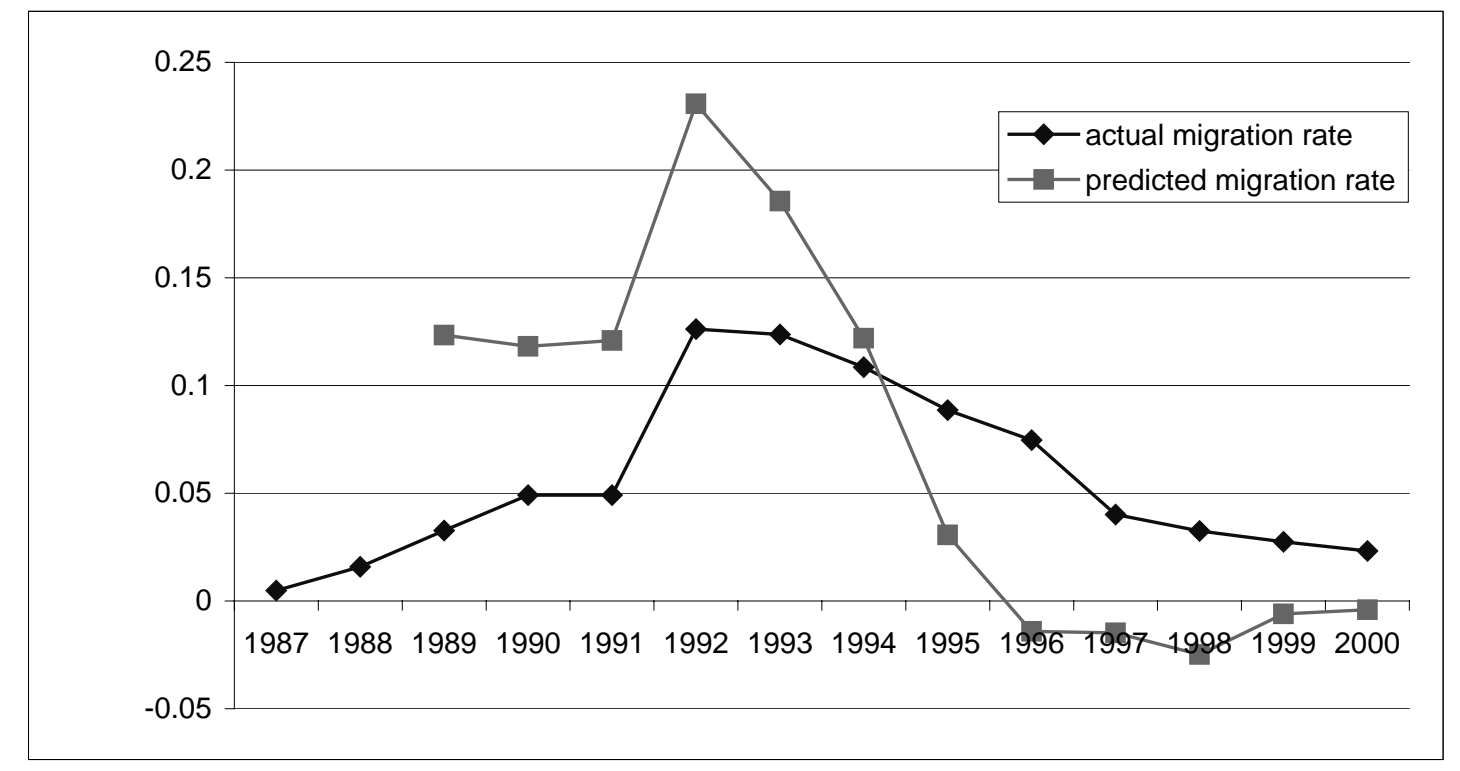

Figure 8a: Actual and predicted unrestricted emigration rate from Kyrgyzstan; $\gamma \approx 0.05, \mathrm{a}_{\mathrm{A}}=0,2, \mathrm{a}_{\mathrm{B}}=0.2, \mathrm{~b}=0.15$ (since 1992) + three-year average of difference in GDP growth rates $/ 100$ 


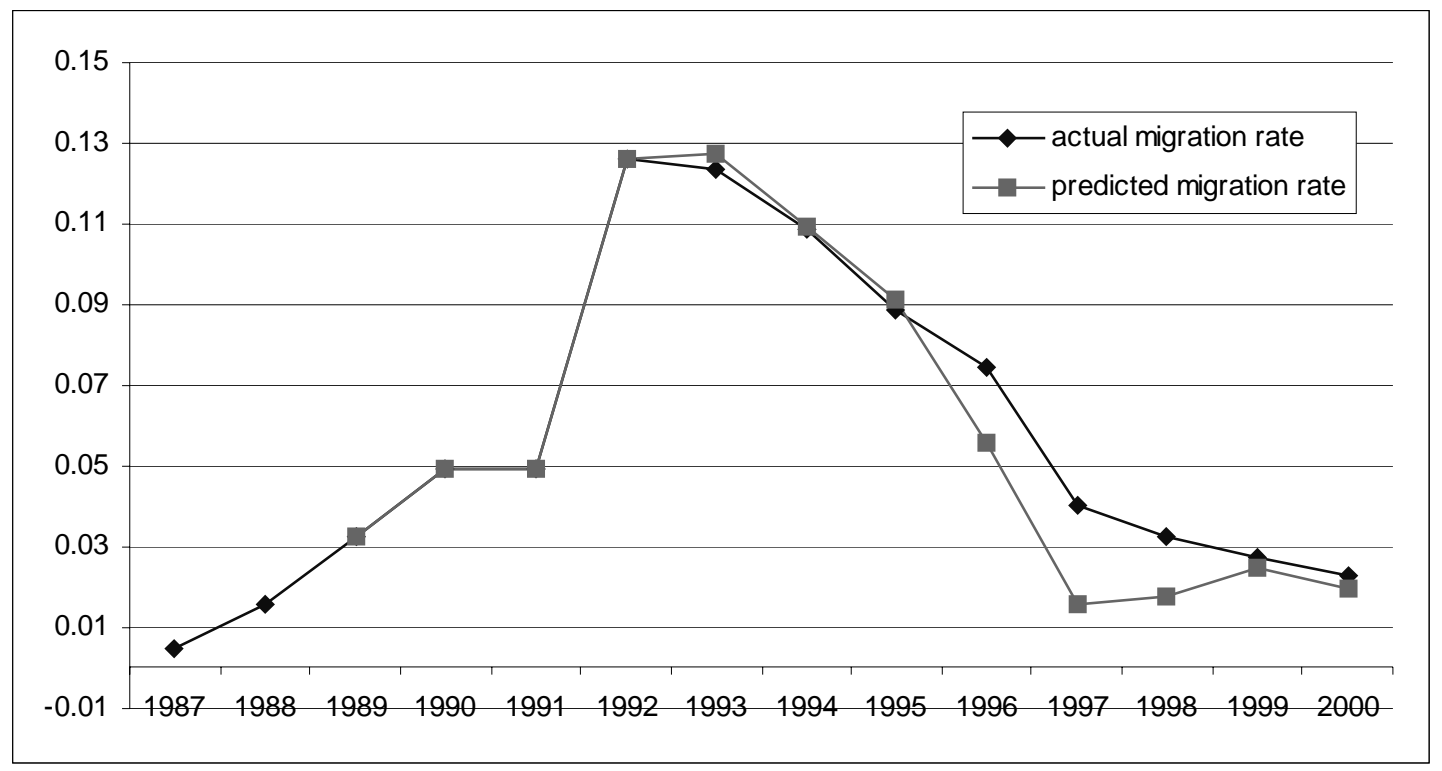

Figure 8b: Actual and predicted restricted emigration rate from Kyrgyzstan; $\gamma \approx 0.05, \mathrm{a}_{\mathrm{A}}=0,2, \mathrm{a}_{\mathrm{B}}=0.2, \mathrm{~b}=0.15$ (since 1992) + three-year average of difference in GDP growth rates/100 


\section{IZA Discussion Papers}
No. Author(s)
270
B. Augurzky
C. M. Schmidt
271
B. Augurzky
C. M. Schmidt
272
C. Belzil
J. Hansen

273

G. Saint-Paul

274

P.J. Pedersen

N. Smith

275

G. S. Epstein

T. Lecker

276

277

B. Amable

D. Gatti

R. Winter-Ebmer

278

T. M. Andersen

279

T. M. Andersen

280

P. Apps

R. Rees

281

G. Saint-Paul

282
J. Albrecht
A. Björklund
S. Vroman

Title

Area

Date

The Evaluation of Community-Based

6

03/01

Interventions: A Monte Carlo Study

The Propensity Score: A Means to An End

6

$03 / 01$

Heterogeneous Returns to Human Capital and

5

03/01

Dynamic Self-Selection

Distribution and Growth in an Economy with

5

03/01

Limited Needs

Unemployment Traps: Do Financial Dis-

3

03/01 incentives Matter?

Multi-Generation Model of Immigrant Earnings:

1

03/01

Theory and Application

The Impact of Product Market Competition on

5

03/01

Employment and Wages

Evaluating an Innovative Redundancy-Retraining

6

03/01

Project: The Austrian Steel Foundation

Welfare Policies, Labour Taxation and Inter-

2

$04 / 01$

national Integration

Product Market Integration, Wage Dispersion

2

04/01 and Unemployment

7

04/01

the Life Cycle

5

04/01

Elites

Is There a Glass Ceiling in Sweden?

5

04/01 

and the Rising Returns to Skill: US and France 1964-2000 
298

P. Telhado Pereira

Returns to Education and Wage Equations
A. Stutzer

R. Lalive

301

J. R. Frick

G. G. Wagner

302

G. S. Epstein

A. Weiss
H. Bonin
G. Abío
E. Berenguer
J. Gil
C. Patxot 
Costs
A. Frederiksen
E. K. Graversen Germany:

Overtime Work, Dual Job Holding and Taxation 

2000 

A. lbourk
B. Maillard
S. Perelman
H. R. Sneessens

The Matching Efficiency of Regional Labour

Markets: A Stochastic Production Frontier

Estimation, France 1990-1995 Industries: A Case Study of Upper Bavaria 